\title{
Engineering thinking and its role in modern industry
}

Cite as: AIP Conference Proceedings 2456, 030033 (2022); https://doi.org/10.1063/5.0074665

Published Online: 18 January 2022

E. A. Putilova and A. V. Shutaleva

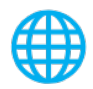

$\underset{\text { Publishing }}{\text { AlP }}$ Author Services

Maximize your publication potential with English language editing and translation services

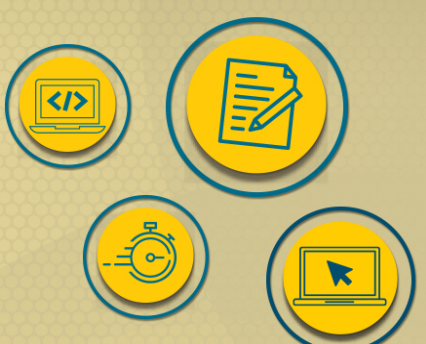

2456, 030033 


\title{
Engineering Thinking and its Role in Modern Industry
}

\author{
E. A. Putilova, a) and A. V. Shutaleva ${ }^{2,3}$ \\ ${ }^{1}$ Ural Federal University named after the First President of Russia B N Yeltsin, Nizhniy Tagil Technological \\ Institute, 59, Krasnogvardeyskaya str., Nizhniy Tagil, 622000, Russia \\ ${ }^{2}$ Ural Federal University named after the first President of Russia B N Yeltsin, 51, Lenin Avenue, Yekaterinburg, \\ 620000, Russia \\ ${ }^{3}$ Ural State Law University, 21, Komsomolskaya, Yekaterinburg, 620137, Russia \\ a)Corresponding author: eazhiltsova@mail.ru
}

\begin{abstract}
The article is devoted to the possibilities of the formation and development of engineering thinking. The paper considers the features of engineering thinking, compares various concepts that characterize engineering activities. The authors compare the concepts of technical, economic, research thinking, identifying the principles of engineering thinking. The need for a humanitarian component in engineering thinking is noted. Consistency and multidimensionality are considered by the authors as the most important concepts for the formation of engineering thinking. In conclusion, the authors point out that engineering thinking universally orients the employee when solving different types of tasks and contributes to greater variability in making standard and non-standard decisions in the production process.
\end{abstract}

\section{INTRODUCTION}

In today's world, the development of society and states is inseparable from the level of development of science and technology. Technological progress has changed the scale and structure of production in industrialized countries. However, technological progress has also had a global impact on the quality of life of people, the ways of communication, and the relationship of people with each other and with the world around them. The constant development of equipment and technology in the modern world leads to a change in the forms and nature of human activity in various spheres, including industrial. The knowledge, skills, and abilities of an employee of an industrial enterprise turn out to be insufficient and a need arises for the formation and development of engineering thinking, which is the most important component of engineering activity. Engineering thinking oriented to solve non-standard problems arising during production, to comprehend critically methods and approaches to solving problems, and to optimize production process.

Further intensification of technological development is the future of humankind development, for which the search for ways of sustainable socio-economic development based on the wider application of new achievements of science and technology is relevant. The development of technologies enhances the role of new technologies in accelerating the pace of development of production, economic and other spheres of society. This fact increases the significance of the creative activity of modern engineers. Indeed, the innovative potential of engineering is the basis for the development of modern national economies. Therefore, it can be argued that engineering education is a strategic resource of a state. Significant parameters for increasing the competitiveness of an enterprise are professional training and retraining of personnel at an industrial enterprise, including the formation and development of engineering thinking. The formation and development of engineering thinking and the development of professional competencies among workers of an industrial enterprise requires an integrated approach and purposeful activity.

The activity of a modern engineer is integrative since the very process of design, content, and technology of engineering work has changed. The design result is the creation of new objects with predetermined characteristics. The project must meet the requirements for the quality of the result, the use of funds and resources, and so on. An engineering project results from a creative activity that operates in technological, ethical, aesthetic, and other categories.

The modern engineer has as the object of his activity the transformation of the human environment. Therefore, the engineer must pursue not only technical but also social goals. The main thing for engineering

Proceedings of the 16th International Conference on Industrial Manufacturing and Metallurgy (ICIMM 2021)

AIP Conf. Proc. 2456, 030033-1-030033-4; https://doi.org/10.1063/5.0074665

Published by AIP Publishing. 978-0-7354-4164-4/\$30.00 
activity is the functional and technological characteristics of the object being created. One of the clearest examples of the object of engineering activity is creating smart and eco-friendly cities. At the same time, modern engineering activities combine technical and socio-humanitarian knowledge since the engineer creates new images of the human environment with the possibilities of a material embodiment of new technologies, materials, and information. Therefore, a philosophical understanding of the formation and development of engineering thinking is necessary since they turn to the worldview, social and methodological issues of further prospects and opportunities for the development of society.

\section{MATERIALS AND METHODS}

In this study, Russian and international monographs and articles devoted to theoretical and practical issues of engineering education have been analyzed. In our research, we proceed from understanding engineering thinking as a systemic one at its core. Therefore, the formation of engineering design thinking [1], universal competencies $[2,3]$, among which the following competencies are of particular importance: communicative competencies [4-7], systems thinking [8], media education [9], team and individual project work [10-12], legal knowledge [13,14], knowledge of socio-humanitarian concepts $[15,16]$ and the ability to apply them in practice. Engineering thinking allows seeing the multidimensionality of the problem (system), its parts (subsystems), their interconnection, as well as its place as a whole (supersystem).

The essential elements of engineering thinking are the ability to see the contradiction (logical, technical, physical) and the ability to concentrate the creative imagination in the required context. The result of this is the design study of the idea, its implementation into an actual project, a new technology.

\section{RESULTS AND DISCUSSION}

Thinkers of the past and present regularly address the issue of engineering thinking, noting its universality in any field, and the accompanying development of critical thinking. Engineers' critical thinking allows them to reapproach old problems with creativity, flexibility, and a desire to improve the world around them. Therefore, interest in the formation and development of engineering thinking was formed quite a long time ago. Thinkers turn to the peculiarities of engineering thinking, principles and norms, worldview guidelines, and ethical components and ideals that form the basis of the creative nature of engineering.

A feature of engineering activity is that it requires a holistic view of the design object, which is especially pronounced when creating smart and environmentally friendly cities [17]. Engineering activity assumes that the engineer knows the language of formulas and the language of drawings and diagrams. At the same time, engineering thinking combines scientific and artistic thinking styles.

Engineering thinking is inextricably linked with science. Since the modern era, the influence of science and technology has become predominant in the development of society. However, this situation led to the consumer attitude of society towards nature and the emergence of global problems. Modern engineering thinking is virtueoriented, and this distinguishes it from the engineering thinking of previous paradigms. The virtue orientation of an engineer's activity presupposes a holistic vision of various processes in their interconnection. The engineer must be able to predict the environmental, social, and ethical consequences of his work. On this basis, it can be argued that engineering thinking goes beyond just technical thinking. An engineer regularly applies integrated scientific knowledge when creating modern objects.

The specificity of the objects of engineering knowledge is their complex nature since these objects include natural and artificial objects: an engineer deals with natural phenomena and with mechanisms, structures that need to be constructed artificially. Therefore, an engineer must have knowledge of natural, technical, economic, and socio-humanitarian sciences.

The development of Industry 4.0 has led to the fact that information technologies has significantly changed the nature and essence of engineering activities and engineering education [18]. Modern engineering projects are complex objects that include aspects of both a technical nature and managerial, social, and other aspects. One of the important aspects of engineering is innovation. In the era of Industry 4.0, the role of innovation becomes crucial. Therefore, engineering education must correspond to these changes. Implementing innovation management in a company is the way that companies cope with market competition and financial crises.

There are two types of innovation in engineering - evolutionary innovation and revolutionary innovation. Evolutionary innovation is based on the continuous and gradual development of technological advances. Revolutionary innovation is the emergence of new technologies that lead to disruptive changes in technologies and processes. The emergence of revolutionary innovations marked the industrial revolutions and the appearance of new types of production. Therefore, a particularly critical question is how to train engineering students so that they become innovators. Innovation and entrepreneurship can be classified in two areas: 
1) innovative materials and tools, and 2) innovation and business models. Engineering technologies have universal principles and patterns, concepts, and methods of activity. The transition to innovative engineering activities in these areas involves strengthening the interdependence of technological progress, social determination, humanistic essence, and the creative nature of engineering. A modern engineer's solution to professional problems depends on the system of knowledge, skills, and values of a specialist since an engineer carries out activities in unpredictable circumstances that complicate the usual routine activity.

A modern engineer deals not only with a specific task but, to a greater extent, with the need to solve the problem posed to him and manage projects in the implementation of which he is directly involved. This form of work requires the engineer to think in terms of the process and define goals and objectives as the project progresses. The new reality of the professional activity of an engineer requires the engineer to have scenario thinking and the ability to act on several alternatives. Therefore, creative learning in the educational process of a higher technical school should take an important place.

In international pedagogical practice, great importance is attached to applying an interdisciplinary approach to the design of curricula and the content of engineering education. The system of effective engineering education at universities presupposes close cooperation with manufacturing enterprises. The forms of interaction between the structures of higher education and industry are the participation of practicing engineers in the educational process of teaching disciplines and the implementation of projects, the joint participation of practical engineers and students in scientific and technical conferences, the study and examples of the practical application of CALS technologies and other forms of interaction of engineers working on production and engineering students.

The modern humanistically oriented educational paradigm leaves its mark on the development of innovative education in a technical university. The modern engineer must be capable of innovative activities that are interdisciplinary and multifunctional. The generalized result of professional engineering education is the preparedness of engineering specialties graduate for social and professional activities.

A modern engineer works at an enterprise in a market environment. This leads to the fact that the engineer begins to show personal, professional qualities for solving standard and non-standard tasks in various social, economic, topological situations.

Many thinkers have defined engineering thinking as technical thinking that helps solve professional intellectual problems to organize technology and create new technical means. The systemic aspect of engineering thinking allows the engineer to quickly and in an original way solve the assigned tasks, see the problem in its entirety, and not segmentally.

Engineering thinking is multidimensional. Engineering thinking is a synthesis of technical, technical economic, constructive, and research thinking. It combines logic, creativity, theoretical and practical orientation, technical, and humanitarian component.

The basic principles of engineering thinking are as follows:

- transformative orientation,

- consistency,

- scientific and theoretical base,

- criticism of thinking,

- constructiveness,

- creativity,

- adaptability.

The formation of engineering thinking is impossible only within the natural science framework, and a humanitarian component is also needed. It is necessary to create a system of continuous education from school through university to dynamic professional activity at the enterprise. This process should be comprehensive, considering the interests of the modern market. For the development of engineering thinking among workers of an industrial enterprise, it is necessary to solve many problems:

- $\quad$ ensuring the interaction of an industrial enterprise with educational organizations,

- support for engineering and technology education,

- popularization of science, technology, engineering,

- access to high-tech equipment,

- information transparency,

- providing conditions for the implementation of the best research results at enterprises and other tasks.

\section{CONCLUSION}

The development of an engineering mindset among industrial workers contributes to more significant variability in making standard and non-standard decisions in the work process and also develops the ability to 
organize people to work more efficiently. Engineering thinking universally orients the employee in solving various types of tasks. Without constant self-improvement and striving for transformation, the development of industrial production in the modern world is impossible.

\section{REFERENCES}

1. C. L. Dym, A. M. Agogino, O. Eris and D. D. Frey. Journal of Engineering Education 94 (1), $103-120$ (2005). doi.org/10.1002/j.2168-9830.2005.tb00832.x.

2. A. Krupkin and M. Sinyakova, Identification of Relevant Interactive Teaching Methods for the Development of Universal Competencies of Future Engineers, Proceedings of the Integrating Engineering Education and Humanities for Global Intercultural Perspectives, St. Petersburg, 2020, 131, 652-658. doi.org/10.1007/978-3-030-47415-7_69.

3. A. Krupkin and N. Gorodnova, XXI International Scientific Conference on Advanced in Civil Engineering "Construction - The Formation of Living Environment" (FORM 2018), Moscow, 2018, (IOP Journal of Physics: Conference Series, 2018), 365 (2). doi.org/10.1088/1757-899X/365/2/022056.

4. E. D. Jansen, Intercultural communication in engineering: a research programme to investigate the cultural influences in the negotiation of engineering projects, Proceedings of the World Transactions on Engineering and Technology Education 1 (01), 7-12 (2002).

5. M. J. Riemer, Global J. of Engineering Education 11 (1), 89-100 (2007).

6. A. Baranova, B. Gusanov and I. Bazhukova, Bulletin of Tomsk State Pedagogical University 2, 60-70 (2021). doi.org/10.23951/1609-624X-2021-2-60-70.

7. A. N. Novgorodtseva and E. A. Belyaeva Perspektivy Nauki i Obrazovania 45 (3), $517-526$ (2020). doi.org/10.32744/pse.2020.3.37.

8. H. Davidz, D. Nightingale and D. Rhodes Enablers and Barriers to Systems Thinking Development: Results of a Qualitative and Quantitative Study, Proceedings of the Conference on Systems Engineering Research, Hoboken, 2005, (INCOSE, 2005).

9. N. B. Kirillova Changing Societies and Personalities 4 (4), $427-440 \quad$ (2020). doi.org/10.15826/CSP.2020.4.4.109.

10. M. Frank, I. Lavy and D. Elata, International Journal of Technology and Design Education 13, 273-288 (2003). doi.org/10.1023/A:1026192113732.

11. M. R. Nalim, M. K. Rajagopa and R. J. Helfenbein Faculty and student perceptions of project-enhanced learning in early engineering education: Barriers, benefits, and breakthroughs, Proceedings of the Annual ASEE Conference and Exposition, Atlanta, 2013.

12. L. N. Bannikova and E. V. Kemmet, Higher education in Russia 28 (12), 66-76 (2019). doi.org/10.31992/0869-3617-2019-28-12-66-76.

13. A. A. Kerimov, O. N. Tomyuk, M. A. Dyachkova and A. Y. Dudchik, Perspektivy Nauki i Obrazovania 45 (3), 459-474 (2020). doi.org/10.32744/pse.2020.3.33.

14. O. N. Tomyuk, M. V. Golysheva, A.Y. Dudchik, M. A. Dyachkova and V. K. Egorov, Perspektivy Nauki i Obrazovania 46 (4), 441-454 (2020). doi.org/10.32744/pse.2020.4.31.

15. M. A. Dyachkova, A. N. Novgorodtseva and O. N. Tomyuk, Perspektivy Nauki i Obrazovania 47 (5), $75-$ 87 (2020). doi.org/10.32744/pse.2020.5.5.

16. O. S. Gilyazova, I. I. Zamoshchanskii and A. N. Zamoshchanskaya, Perspektivy Nauki i Obrazovania 46 (4), 10-22 (2020). doi.org/10.32744/pse.2020.4.1.

17. A. Krupkin and M. Sinyakova, Identification of Relevant Interactive Teaching Methods for the Development of Universal Competencies of Future Engineers, Proceedings of the Integrating Engineering Education and Humanities for Global Intercultural Perspective, St. Petersburg, 2020, 131, 652-658. doi.org/10.1007/978-3-030-47415-7_69.

18. E. Cevikcan, A. Ustundag, C. Kadaifci and B. Oztaysi, in Industry 4.0: Managing the Digital Transformation. Springer Series in Advanced Manufacturing, 137-151 (2018). doi.org/10.1007/978-3-31957870-5_8. 